\title{
Rola barwy w kształtowaniu przestrzeni publicznych współczesnych miast
}

\section{The role of colour in shaping public spaces of contemporary cities}

\begin{abstract}
Streszczenie
Wpływ barwy na środowisko życia w miastach, w tym środowisko mieszkaniowe jest ogromny, ale rola tego czynnika jest zbyt mało doceniana w kształtowaniu krajobrazu miasta. Artykuł przedstawia zagadnienie roli barwy w kompozycji najnowszych rozwiązań urbanistycznych i krajobrazowych w miastach.

Główne cele badań prezentowanych w artykule są następujące: 1) wskazanie możliwości wykorzystania barwy w kompozycji urbanistycznej oraz 2) wskazanie współczesnych rozwiązań urbanistycznych i krajobrazowych, stanowiących wybitne przykłady wykorzystania i zastosowania barwy w przestrzeniach publicznych współczesnych miast.

Podjęte badania zostały zrealizowane przy uwzględnieniu istniejącego stanu wiedzy i zastosowaniu metod badawczych odpowiednich dla morfologicznych badań przestrzeni miejskiej: 1) metoda analizy i krytyki źródeł (dokumentów planistycznych, literatury, projektów), 2) metoda obserwacyjna (zastosowana do oceny stanu istniejącego), 3) metoda porównawcza.
\end{abstract}

\section{Summary}

The influence of colour on the living environment in cities, including the housing environment is huge, but the role of this factor is too little appreciated in shaping the townscape. The article presents the issue of the role of colour in the composition of the newest urban and landscape design solutions in cities.

The main purposes of the research presented in the article are following: 1) indication of the possibility of the use colour in urban composition and 2) indication of contemporary urban and landscape solutions, which are outstanding examples of the use and application of colour in public spaces of contemporary cities.

The research undertaken has been implemented taking into account the existing state of knowledge and the use of research methods appropriate for morphological research of urban space: 1) method of analysis and criticism of sources (planning documents, literature, projects), 2) observation method (used to assess the existing state), 3) comparative method.

Słowa kluczowe: barwa, przestrzeń publiczna, założenia urbanistyczne i krajobrazowe, miasto, kompozycja Keywords: colour, public space, urban and landscape solutions, city, composition

\section{Wprowadzenie}

W ostatnim kwartale XX-tego oraz na początku XXI wieku nastąpił znaczny rozwój przestrzeni publicznych, co przejawiło się $\mathrm{w}$ wielu realizacjach rewitalizacji istniejących przestrzeni publicznych oraz kreacji nowych przestrzeni. Obecnie można zaobserwować wysoką jakość wielu rozwiązań przestrzeni publicznych, a ważną rolę w kształtowaniu ich tożsamości odgrywa barwa.

„Barwa jest ttem wielu doznań estetycznych, a jednocześnie zawsze ttem doznań przestrzennych, towarzyszących stale człowiekowi. Tworzy ona charakterystyczne cechy środowiska - dodatnie lub ujemne - wptywające na przeżycia psychiczne użytkowników lub przygodnych obserwatorów. Stały, długotrwały kontakt człowieka ze środowiskiem przygnębiającym barwą, środowiskiem

\section{Introduction}

In the last quarter of the 20th and at the beginning of the 21 st century, there was a significant development of public spaces, which was manifested in many realizations of the revitalization of existing public spaces and in the creation of new spaces. At present, high quality of many solutions of public spaces can be observed, and colour plays an important role in shaping their identity.

"The colour is the background of many aesthetic experiences, and at the same time a/ways the background of spatial experiences that accompany people constantly. It creates characteristic features of the environment positive or negative - affecting the psychic experience 
czarnym, szarym lub odwrotnie pogodnym, jasnym pozostawia mocny slad na jego psychice

"W swiadomie ksztattowanych układach można tworzyc kompozycje barwne w przestrzeni i czasie"

Kształtowanie współczesnego krajobrazu miasta powinno być oparte o zasady kompozycji urbanistycznej powinno korzystac zarówno $z$ wieloletnich doświadcze kultury budowy miast, jak i ze współczesnych osiągnięc techniki $i$ technologii. Jednym z podstawowych elementów kompozycji urbanistycznej jest podłoga urbanistyczna o różnym układzie topograficznym, w które stosuje się różnorodne motywy barwne. Wykorzystywanie barwy w kompozycji założeń urbanistycznych i krajomiejsca a nawet catego miasta.

\section{Rola barwy w krajobrazie miast}

Kształtowanie barwnego krajobrazu miejskiego, w tym zespołów urbanistycznych i przestrzeni publing ýn jest przedzony skomplikowanym, który powich byc joszaru, a nawet całego miasta.

Każde miasto posiada swój odrębny koloryt lokalny powstajacy na tle charakterystycznych cech geograficznych, klimatycznych i przyrodniczych. Cechy te wystepuia w zabarwieniu i jasności stropu nieba, liczbie dni stonecznych, intensywności światta oraz barwie roślinności, jej ubóstwie czy bogactwie. ... Suma tych czynników staje się przestanką nie tylko dla powtarzania określonej tonacji tącznej środowiska, ale i dla ksztattowania cech budynków i przestrzeni otwartych"'s. (II. 1-3)

Kolejnym czynnikiem wpływającym na powstawanie lokalnego kolorytu miasta jest stosowanie miejscowych materiałów budowlanych: kamienia, cegly, dachowki, tle tradycji i przyzwyczajeń stosowania powtarzalnych barw tynków stolarki i innych elementów budowlanych a nawet zasłon okiennych, okiennic czy markiz. Dawnie na koloryt barwny miasta w znacznym stopniu wpływa związek położenia miasta z lokalnym źródłem surowców, gdyż dowóz materiałów z daleka był utrudniony. Istniały także silne tradycje rodzime budownictwa, a napływ in formacji z innych regionow czy krajów był powolny. Stąd przejmowanie wzorow z odległych obszarów było bardzo rzadkie. Dzisiaj przemystowa produkcja materiałów i bardzo szybkie przekazywanie fachowych informacji zmniej-

strzenia stwarza warunki do komponowanianie przezespotóm otwieraiac szerokie możliwości dla stosowania barwy ${ }^{\prime \prime 5}$.

Zazimierza Wejcherta zawsze powinna byc once indywidualna koncepcja urbanistyczistycznych walorach, zaplanowana również jako całościowa kompozycja kolorystyczna zespołu urbanistycznego lub przestrzeni publicznej6.

„Dzięki wprowadzeniu barwy jako czynnika kompozyci przestrzeni można, prócz wrażeń ściśle estetycznych dajacych zadowolenie z zestawienia plam barwnych. uzyskać odczucie tonacji ogólnej zespołu wptywajace na stan psychiczny człowieka"... „Nowoczesne materiały of users or casual observers. Permanent, long-lasting cause of colour, black, grey or vice versa, bright environment, leaves a strong mark on his psychem.

"It is possible to create colourful compositions in space and time in consciously shaped systems"

Shaping of the contemporary townscape should be based on the principles of urban composition, should benefit both from many years of experience of culture of building cities, as well as from the contemporary achever of the urban composition is the urban floor with vari-

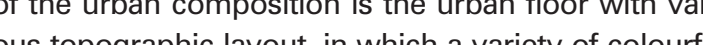
motifs are used The use of colou in of urban and lande use solutions affects shaping ide

\section{The role of colour in the urban landscape}

Shaping the colourful urban landscape, including urban complexes and public spaces is a complicated process, which should be preceded by studies on the local colour of the area, and even the entire city. Each city has its own distinct local colouring influenced by geographical, climatic and natural characteristics. "These features occur in the colour and brightness of the sky celling, the number of sunny days, the intensity of light and the colour of vegetation, its poverty or richness.... The sum of these factors becomes a premise not only for repeating a certain tone of the total environment, but also for shaping the features of buildings and open spaces"'s. (III. 1-3)

Another factor influencing the local colouring of the city is the use of local building materials: stone, brick, tile, slate or clay for the production of paints and the creation of tradition and habits of using repetitive colours of plasters, window-frames and other building lements, and even window curtains, shuters or marquees. In the past the city's colour was largely influace the the pation locis source of raw materias, because delivery

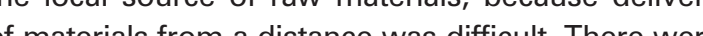
aso strong tradilins of nave constucion, and the ing of was stow Hence, taking over pattens from distant arwas slow. Hence, taking over pattens from distant areas was very rare. Today, industrial production of materials and very fast transferring of professional information reduces the individualiy of the city's colour'. However, at present "planned spatial management reates conditions for composing large complexes, opening up wide possibilities for the use of colour". According to Kazimierz Wejchert, an individual urba concept of humanistic values should always be designed, planned also as a total colour composition of urban complex or public space

"Thanks to the introduction of colour as a factor of the composition of space, it is possible apart from strictly aesthetic impressions, that give satisfaction
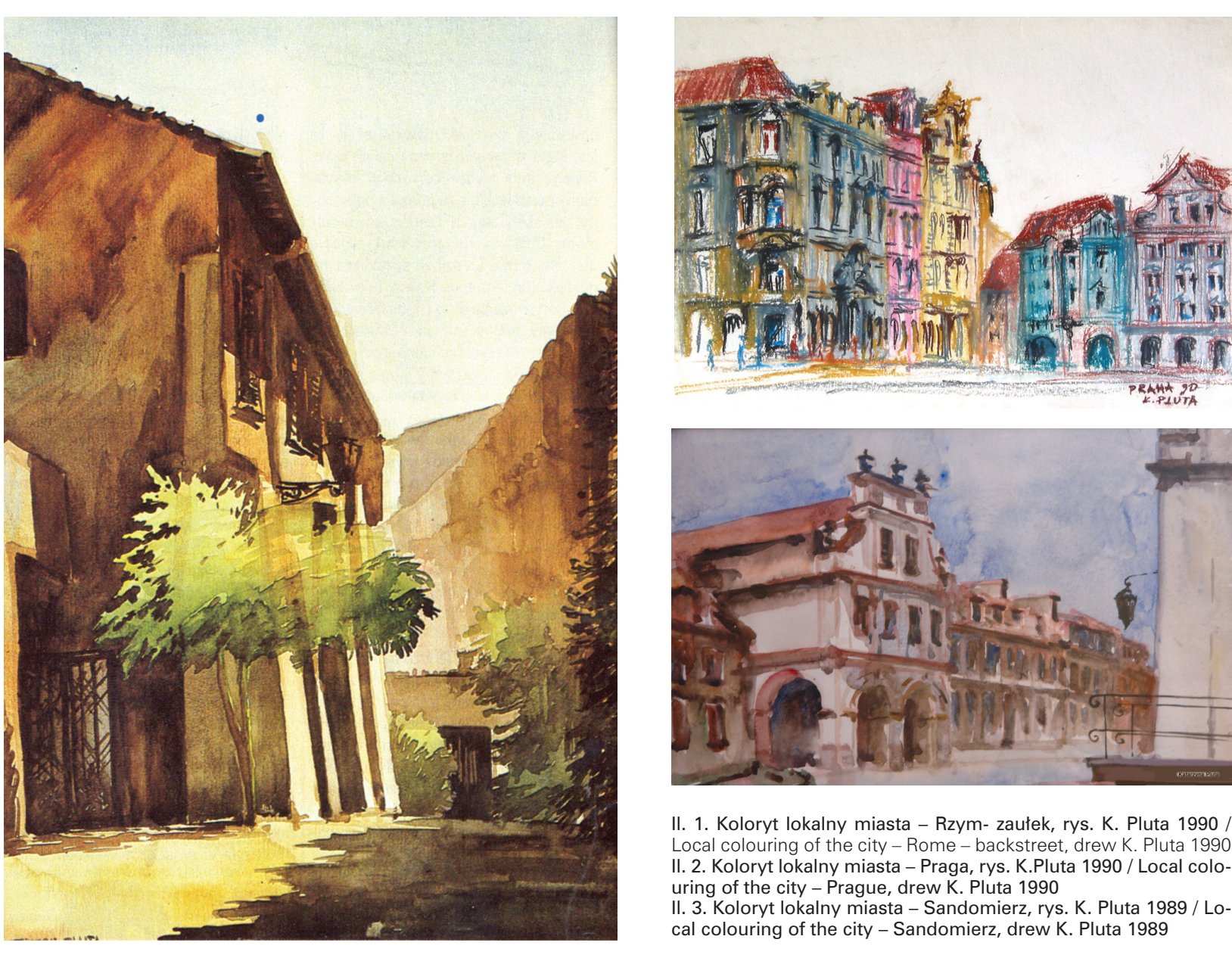
II. 1. Koloryt lokalny miasta - Rzym- zautek, rys. K. Pluta 1990 /
Local colouring of the city - Rome - - ackstreet, drew K. Pluta 1990 -
II. 2. Koloryt lokalny miasta - Praga, rys. K.Pluta 1990 / Local colouring of the city - Prague, drew K. Pluta 1990
II. 3. Koloryt lokalny miasta - Sandomierz, rys. K. Pluta 1989 / LO-

budowlane, jak blachy, lakiery, trwate różnobarwne powhoki materialow tradycyinych pozwa waja na uzycie niemal wszystkich barw znajdujących się w skali Maxwella"

Procesy związane z podkreślaniem roli barwy w krajobrazie wspótczesnych miast można podzielić na dwa główne kierunki: 1) rewitalizacja istniejących założeń 2) kształtowanie nowych założen

W procesie rewitalizacji istniejących założeń należy wymienić następujące istotne sposoby działania dotyczące astosowania barwy:

1) Projekty kolorystyczne zespołów zabytkowych przy okazji renowacji elewacji lub odbudowy, przebudow wszystkim ciagów ulic i placów. Przykładem jest odbu dowa Starego Miasta w Warszawie, Rynku staromiejskiego w Poznaniu i we Wrześni.

2) Projekty dotyczace "cczyszczenia" elewacji budowli, które sa przybrudzone, poczerniałe, pokryte patyna, sa dzami, wykwitami wilgotnych plam, a czasami pocryte płatami uszkodzeń. Przykładem jest proces oczyszczenia zabudowy Paryża w latach 1964-1968 przez przywrócenie wielu jego zabytkom pierwotnej żółtawo-złotej barwy kamienia, z którego były wnoszone.

W kształtowaniu nowych zespołów urbanistycznych przestrzeni publicznych stosuje sie nastepujące sposo- because of combination of colour patches, get the mpression of the general tone of the complex at fecting the psychological state of man" ... "Moder building materials, such as sheets, varnishes, durable multicolour coatings of traditional materials allow to use almost all colours on the Maxwell scale" Processes related to emphasizing the role of colour in Pe townsape of contemporary cities can be divided into two main directions: 1) revitalization of existing structures, 2) shaping new solutions.

In the process of revitalizing the existing structures, the following important ways of use of colour should be mentioned:

Colour designs of historical complexes during the renovation of the facade or reconstruction and modernization of the Old Town districts, including, above all, streets and squares. An example is the reconstruction of the Old Town in Warsaw, the Old Town Square in Poznań and Września.

2) Projects concerning the "cleansing" of facades of buildings that are soiled, blackened, covered with patina, cinders, blooms of moist stains, and sometimes covered with patches of damage. An examin 1964-1968 by restoring many of its monuments ple is the process of cleaning the buildings in Paris 
by działania dotyczące zastosowania barwy jako istotnego czynnika wplywającego na koncepcję zalożenia:

1) Należy uwzględniac następujące zjawiska: pozorne przyblizanie się barw ciemnych i oddalanie jasnych oraz zjawisko irradiacji, polegające na pozornej zmianie wielkości plam kontrastujących ze sobą, zwłaszcza biel czerni;

2) Stosowanie materiałów budowlanych o trwałych barwach (beton, klinkier, cegła w różnych kolorach, drewno, szkło, elementy okładzin metalowych itp.);

) Malowanie całego budynku jednym, przeważającym olorem;

4) Stosowanie faktur mieszanych (tynków szlachetnych i faktur gresowych) na gotowych elementach prefabrykowanych

Whych struktury i detalu budynku (stroów, pionów konstrukcyjnych, loggii, balkonów, zwieńBor

Barwne rozwiązania elewacji zespołu budynków, powa wnych, malowanie budynków w zespole $z$ uwzglednie iem punktów widokowych: Użycie powierzchni typu czenie, a także niekiedy ukazującej, przy odpowiednim kierunku światła, wnętrze budynku:

8) Wykorzystanie bogatej kolorystyki zieleni (charakterystyczny koloryt różnych gatunków drzew, krzewów (kwiatów, zmienność kolorytu w porach roku): 9) Barwne rozwiązanie podłogi urbanistycznej;

10) Projekty kolorystyczne zespołów urbanistycznych i przestrzeni publicznych -całościowa kompozycja kolorystyczna danego zespołu, przestrzeni;

11) Ksztaltowanie barwnego krajobrazu miejskiego za pomocą oświetlenia sztucznego (zmienność w czasie, motyw ruchu, efekty typu „wystawowego")

Współczesne miasta, zwłaszcza duże to skomplikowae struktury funkcjonalno- przestrzenne, w których barwa odgrywa często ważną rolę. Podkreslic należy, że uwzględnianie istniejących lub wprowadzanie nowych lementów barwnych jest procesem $w$ różnych skalach. the original yellowish-gold colour of the stone, from which they were built ${ }^{8}$.

In shaping new urban complexes and public spaces, the following ways of applying the colour as an im1) The following phenomena should be taken into account: the apparent approach of dark colours and the distance of light ones and the phenomenon of irradition consisting in an apparent change in the size of

2) The use of building materials of permanent (1) wood, ) Painting the whole bilding with ong predonina

one predominant

The use of mixed textures (precious plasters and gres surfaces) on finished prefabricated elements; 5) Emphasizing of the structure and detail of building conies, crowns, cross-sectional walls,

6) Coloured solutions of facade of building complex repetition of a given colour on subsequent building in the complex, application of colour accents in the complex, painting of buildings in the complex taking into consideration viewpoints

7) Using a mirror type surface reflecting the surroundings and sometimes showing, in the right direction of the light, the interior of the building

8) The use of a rich colour of greenery (characteristic ers, change colours in seasons :

9) A colourful solution for an urban floor

10) Colour design conception of entire urban complexes and public spaces - a total colour compostion of the complex space.

11) Shaping a colourful urban landscape with artificial lighting (variability in time, movement, "exhibition" effects) $)^{9}$. portant factor affecting the design concept are used: contrasting patches, especially white and the by colour (cellings, structural divisions, loggias, ba colour of various species of trees, shrubs and flow-

II. 4. Zespót Spreebogen, Berlin, fot. K. Pluta 2010 / Spreebogen Complex, Berlin, photo K. Pluta 2010

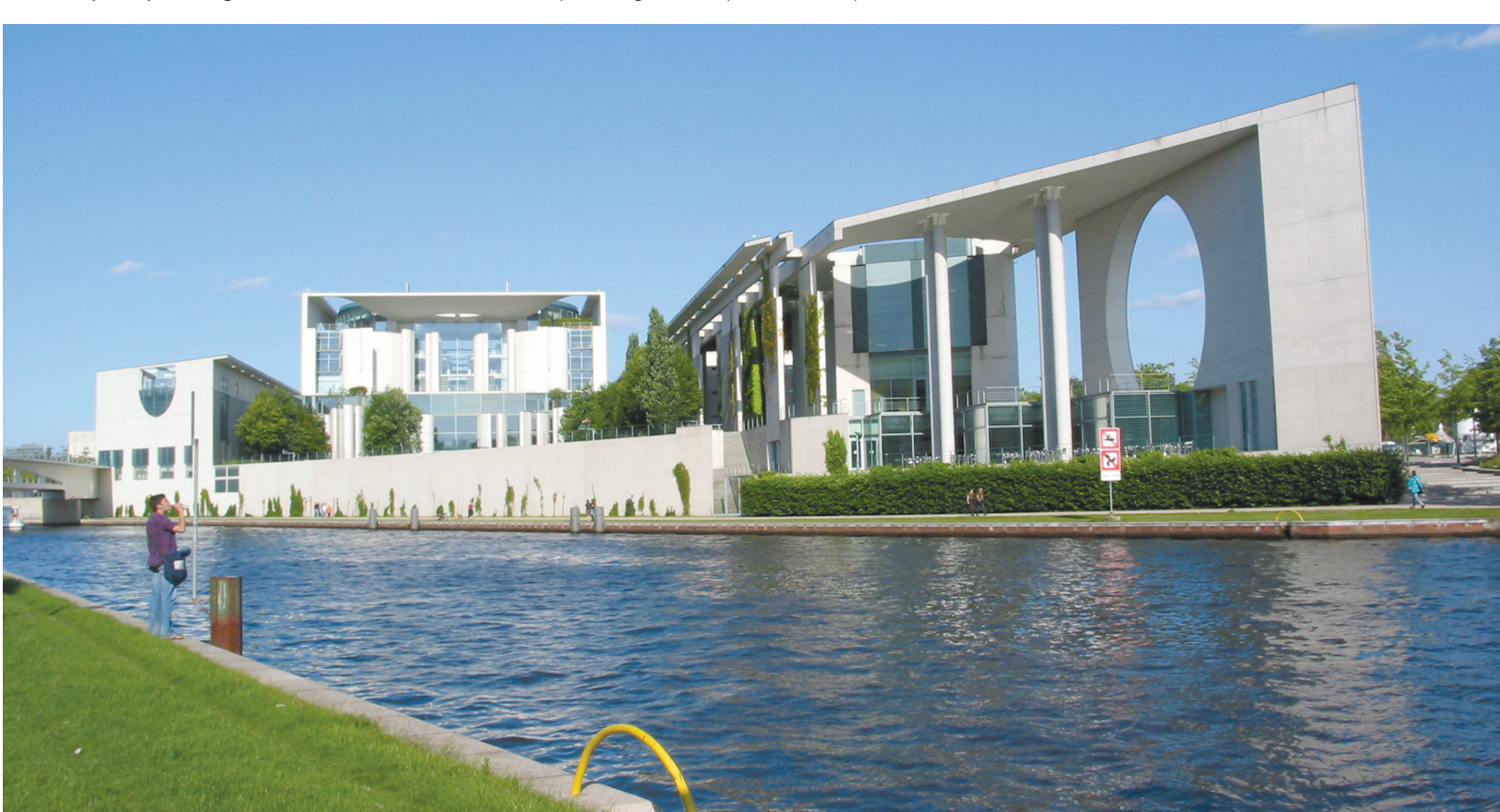

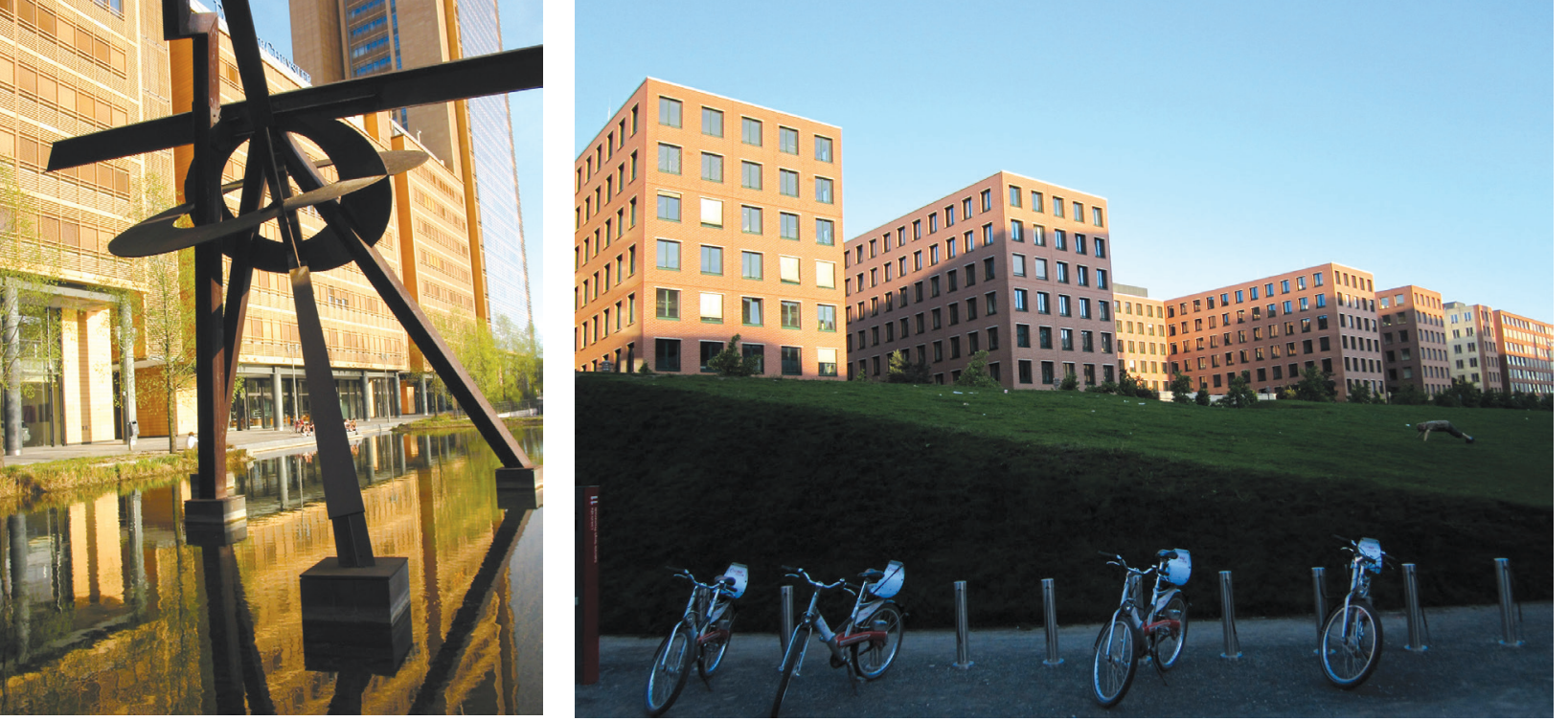

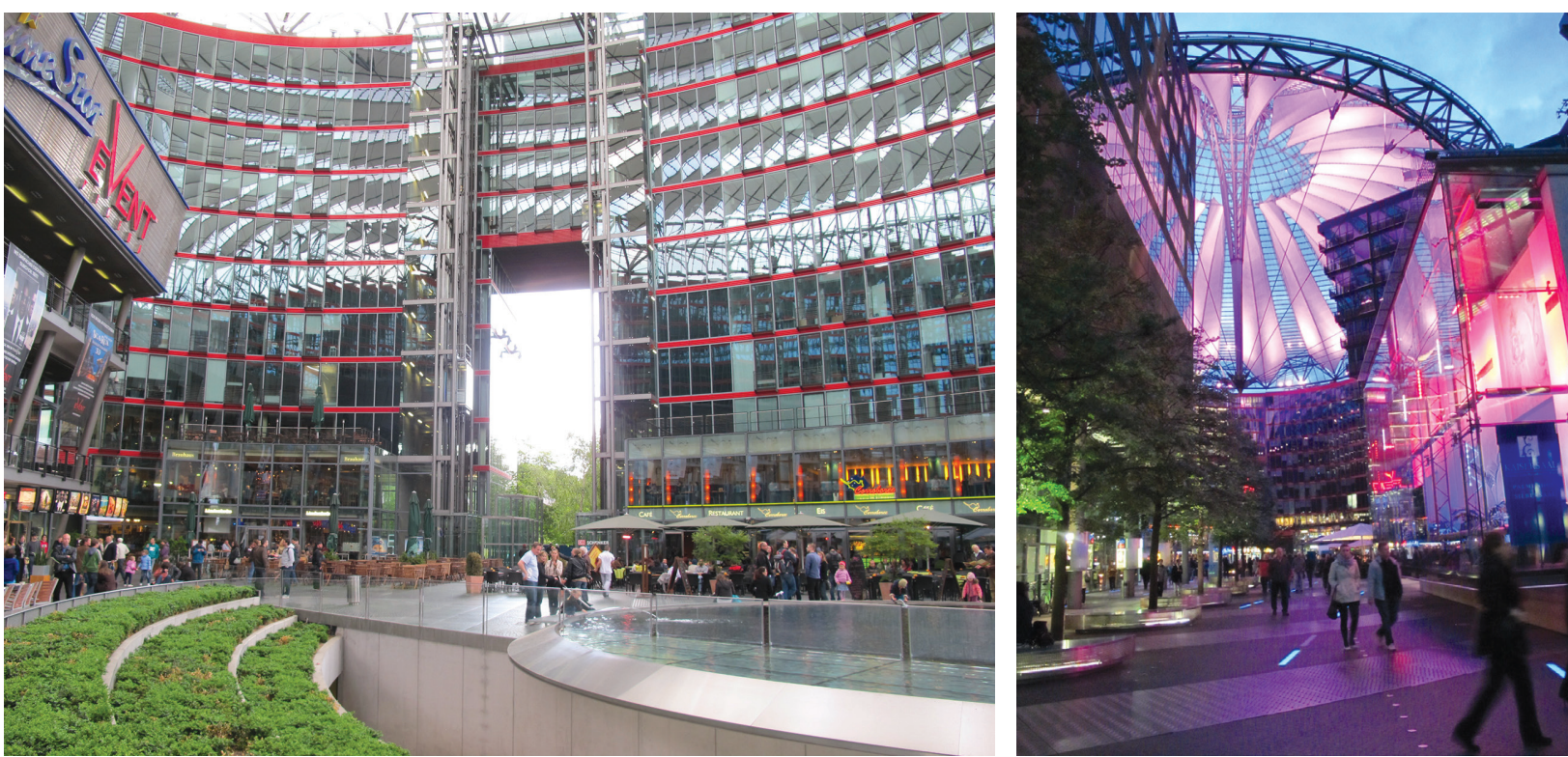

5. Zespół Potsdamer Platz - kwartał Daimler-Benz, fot. K. Pluta 2007 / Potsdamer Platz - quarter of Daimler-Benz, photo K. Pluta 2007

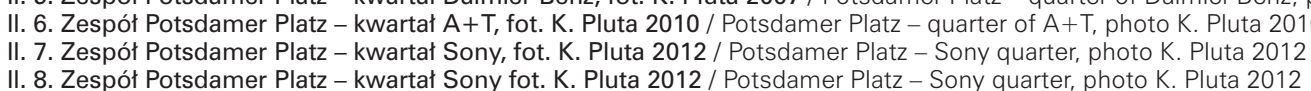

W skali największej, w planowaniu rozwoju miasta przekształceniom poddawane są obszary zwane "terrain va gue (czyll puste, nilezagospodarowane), ktore znajduja się $w$ centralnych częśliach miast oraz na peryferiach. $W$ procesach restrukturyzacjí i regeneracji tkanki dużych miast za pomoca projektów urbanistycznych w duże

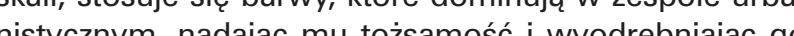
wrajobrazio miasta Przykładem możo być ocbsaając go icy rzadowej Spreebogen w Berlinie (proj Axel Schultes i Charlotte Frank, 1992), któremu berwej nadaj gtónni dwa materiały stosowane w zespole: beton i szkło (Il. 4l) Obszar Daimler-Benz o przeważajacych kamienno-szkl nych fasadach w wielofunkyinym zespole Potsdamer Platz w Berlinie (projekt planu ogólnego -Heinz Hilmer i Christoph Sattler) ma barwe w odcieniach szarfanu (żótto-pomarańczowa), obszar A+T posiada wszystkie budynki o fasadach w barwie ceglastej, a materiały użyte na fasadach w kwartale Sony Center to głównie stal i szkło (kwartał Sony- proj. Helmut Jahn, kwartał A+T -proj.
Contemporary cities, especially large ones, are complex functional and spatial structures in which colour often plays an important role. It should be emphasized that taking into account existing or introducing new colour elements is a process at various scales. In the largest scale, in the planning of the city's development, the areas referred to as "terrain vague" are transformed (i.e. empty, undeveloped), which are located in the central parts of cities and on the peripheries.

In the processes of restructuring and regeneration of large cities by means of urban projects on a large scale, there are used colours that dominate in the urban complex, giving it identity and distinguishing it in the townscape. An example is the area of the Spreebogen government district in Berlin (designed by Axel Schultes and Charlotte Frank, 1992), whose colour is mainly given by two materials used in the complex: concrete and glass. (III. 4) Daimler-Benz area 
For example, at the Magellan-Terrassen coasta square in the Hafenciy complex in Hamburg, the bright building materials used on the square floo and darker artistically composed sea ornaments and mosaics resemble the maritime past of the area and emphasize the character of the terraces as an urban square (design by EMBT Arquitectes Associates, SL Barcelona, WES \& Partner, Hamburg, 2005-2010)15. (III. 14)

In the Westhafen coastal area in Frankfurt am Main new buildings emphasize the character of the former port thanks to the red sandstone facades along with porth grey-black basalt (

On a large scale there are also shaped areas and public spaces serving the dissemination of knowledge and innovation, including open science festivals, large exhibitions of inventions, world exhibitions Expo, gardening exhibitions ${ }^{17}$.

An example of the application of the colour, determining the identity of the area, is the area called Buga 2005 in the Messestadt Riem district in Munich - the place where the German National Horticultural Exhibition was organized (designed by Rainer Schmid RSLA, Munich, 2005). There are themed garden located irregularly in fields of various shapes and connected by a system of walking paths. In the part called "Garden of Power" the bright red plastic elements were used as the leading motif

The global initiatives that have a major impact on the spatial structure of cities include shaping of Olympic areas along with new public spaces.

The interesting example is main public space in the Sydney Olympic Park in Sydney (designed by ASPECT Studios, Mc Gregor Westlake Architects, Deuce Design, completion 2008) consists of severa Deure Design, comc Grion 2008) consis of sever, with a group of trees, low walls which are the bound wires of space and openwork light construction providing she ${ }^{19}$. In the composition of this public providing spublic space an import various shades. Besides the dominant green grass surface (in the plan in the shape of a circle segment), the green colour has both glass roofing of the ligh construction and fragments of border walls. The spatial element that has the strongest influence on the observer is the linear roof shaped in the plan on the curve line, which is the element that guides the eyesight. Three rows of rectangular glass panels are additionally divided by transverse construction elements, which creates rectangular fields filled with colored glass, which differ in shades.

In a large scale there is also a process of modernization and rehabilitation of large prefabricated housing estates, in which colour is an important factor of shaping the identity of complexes, including the creation of colour compositions that differentiate dzącym wzrok. Trzy rzędy prostokątnych paneli szklanych podzielone sa dodatkowo elementami konstrukcyjnym poprzecznymi, co tworzy prostokątne pola wypełnion barwionym szkłem rozniącym się odcieniami.

W dużej skali występuje także proces modernizacji i rehabilitacji dużych prefabrykowanych osiedli mieszkaniowych, w ktorym barwa jest istotnym czynnikiem ksztatowania tożsamosci zalożen, w tym następuje tworzenie kompozycji barwnych odróżniających zespoły od siebie. Jednym z najciekawszych przykładów są kompleksowe próby modernizacji osiedli w Berlinie (np. balkony $w$ barwie żottej i czerwonej jako detal ksztaltujący tożsa mośc osiedla, narożnik kwartalu w silnej barwie czerwo nej - jako akcent przestrzenny, itp.).

W skali mniejszej zastosowanie barwy widoczne jest W kszlathowaniu przestzeni publicznych współczesmiejkich. Obecnie zastosowanie wszelkiego rodzaju lementów barwnych w projektach rewitalizacii tego rodzaju przestrzeni publicznych oraz w projektach nowych przestrzeni publicznych jest bardzo czeste. Podjete ba dania dotyczace zagadnienia roli barwy w krajobrazie miasta, a w szczególności w kompozycii współczesnych rozwiązań urbanistycznych i krajobrazowych koncentrowały się głównie na przestrzeniach publicznych. Wièkszość przestrzeni publicznych posiada całościowa oryginalna koncepcje kolorystyczna. Jednakże ze wzgledu na bardzo duża ilość rozmaitych rozwiazzan, w artykule przedstawione są głównie przykłady przestrzeni publicznych, w których barwa w znacznym stopniu wpływa na tożsamość danego założenia.

Na placach stosuje się elementy barwne o różnych ksztaltach, wspoltworzące podłogę wnętrza urbanistycz nego i podkreslające często charakter kompozycji wnętrza urbanistycznego placu lub ulicy. (II. 16, 17)

3. Barwne rozwiązanie podłogi urbanistyczne W Genewie w Szwajcarii zrealizowano Place Des Nations - plac, w Którym zastosowano róznobarwne nawierzchnie posadzki (proj. Christian Drewet architecture, Arlette Ortis, Sandra Robyr, 2007). Prostokątny plac podzielony jest na szerokie pasy prostopadłe do glownej osi. Pasy wykonane sa z naprzemiennie z granitowej kostki brukowej z 20 krajow w wielu kolorach przechodzących od barw zimnych do ciepłych (9 pasm) oraz z betonu (7 pasm, $w$ kazdym pasmie usytuowano tem przestrzennym placu jest przeskalowane krzesło the complexes from each other. One of the most inexples are comprehensive attenp modernize housing estates in Berlin (e.g. balconies in yellow and red as a detail shaping the identity of the housing estate, the corner of the quarter in a strong red colour - as a spatial accent, etc.).

In a smaller scale, the application of colour is visible in shaping of public spaces of contemporary cities, primarily streets, squares and city parks. Currently, the use of all kinds of colour elements in revitalization projects of this type of public spaces and in the design of new public spaces is very common. The lour in the tows and in particular in the comporition of contemporay uban and landscape soltPons, focused mainy on public spaces. Most publc spaces have a compro pubic sparina colour concept. Howve a colye to a very large number of varous selus, the a a very large number of varicus sos, in which the colour las examples of public tity of a space.

On the squares, colourful elements of various shapes are used, co-creating the floor of the urban interior and often emphasizing the character of the composition of the urban interior of the square or street. (III. 16, 17)

3. A colourful solution of an urban floo

In Geneva in Switzerland, there was realized Place Des Nations - a square, in which coloured floors were used (designed by Christian Drewet architecture, Arlette Ortis, Sandra Robyr, completion 2007). The rectangular square is divided into wide belts perpendicular to the main axis. The belts are made alternately by granite cobblestones from 20 countries in many colours (changing from cold to warm colours, 9 belts) and from concrete $(7$ belts, each with 12 streams of water situated in row) ${ }^{20}$.

The dominant spatial element of the square is the chair in a large scale in dark brown colou. Tha to the colouful stone stipes, the floor of the square colloult that is a distinctive ele ment in the townscape.

One of the most interesting examples of the use of colour in public space open to water is the Grand $\mathrm{Ca}$

lekkiej zapewniajacej cieńn ${ }^{19}$ powierzchni zielonej trawiastej (na planie w kszid cinka koła), zieloną barwę ma zarówno szklane zada nie konstrukcji lekkiej, jak i fragmenty ścian oporowych granicznych. Elementem przestrzennym naisiniejo łującym na obserwatora jest liniowe zadaszenie uksztatowane w planie na łuku, które jest elementem prowa-

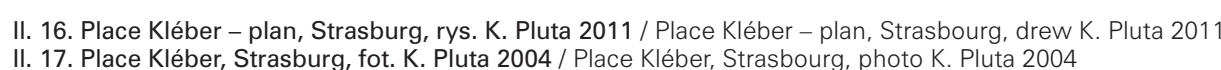

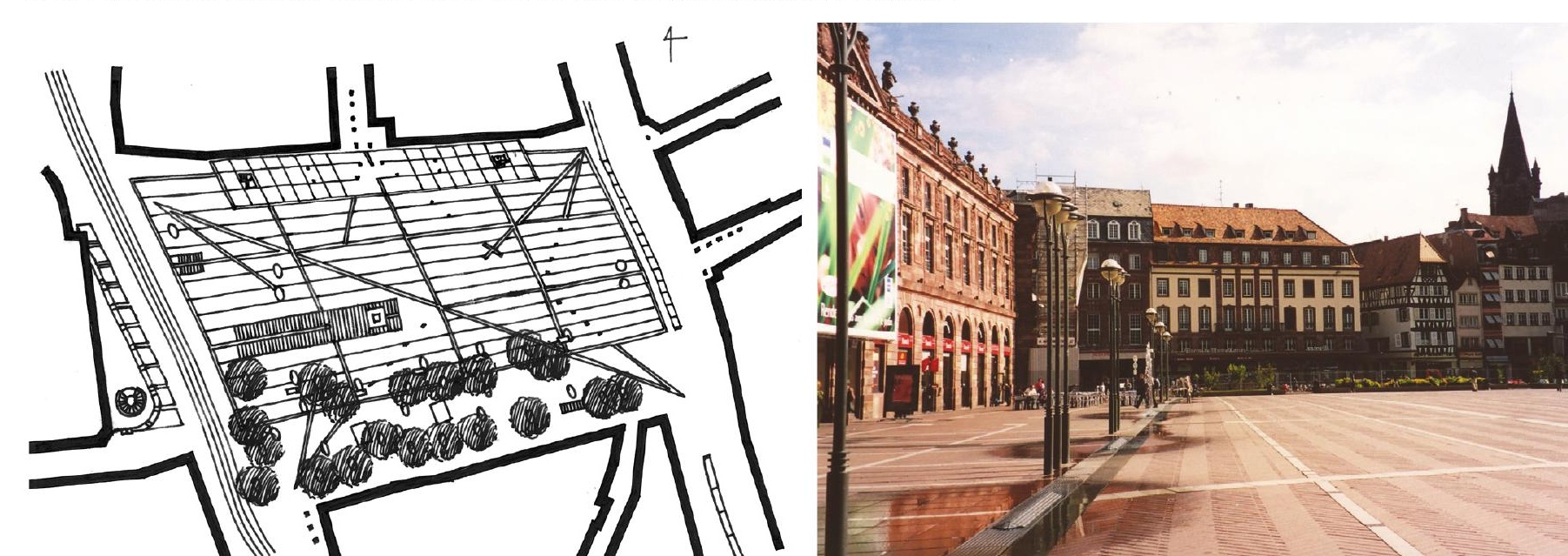


w barwie ciemnobrązowej. Dzięki barwnym kamiennym pasom posadzka placu przypomina barwny dywan stanowiący wyrożiający się element w krajobrazie miasta. Jednym z najbardziej interesujących przykładów zastosowania barwy w przestrzeni publicznej otwartej n wodę jest projekt Grand Canal Square w Dublinie (proj Martha Schwartz, Martha Schwartz Partners, 2007). Plac podzielony został na trójkątne pola za pomocą linii w posadzce, wypełnionych powierzchniami utwardzonym w różnych barwach, powierzchniami trawiastymi i zielenią niska. Głównym elementem przestrzennym placu jest czerwony pas nawierzchni łączący Grand Canal z teatrem Studio Daniela Libeskinda nazwany "czerwonym dywanem" $i$ uzupełniony grupami lamp w formie wysokich smukłych słupów w barwie czerwonej. Drugi pas przecina plac tącząc obiekty hotelu i i biura ${ }^{21}$.

Kompozycja placu jest dynamiczna, podporządkowana otwarciu i ukierunkowaniu na wode. Kierunek ton podkreślony jest przede wszystkim za pomoca pasa i lamp w barwie czerwonej, co nadaje tej przestrzeni bardzo indywidualna tożsamość. W nocy plac ma odmienna tonacje kolorystyczna - dominuja wtedy dwie barwy: czerwona (stupy lamp) oraz zielona (podświetlone brzegi trójkątnych pól zielonego pasa).

\section{Rola barwy we wnętrzu urbanistycznym kierunko-} wym

Jednym z najciekawszych przykładów wykorzystania barwy w rewitalizacji przestrzeni publicznej o cechach wnętrza kierunkowego jest projekt Superkilen w Kopenhadze (proj. Topotek 1, BIG Architects, Superflex realizacja 2012). Podfuzna pusta przestizen w zwarte zabudowie centrum miasta podzielona została na trzy strefy o odmiennym sposobie użytkowania: Green Park (liniowy park jako najduzzsza strefa), Black Market (strefa przejściowa o ciemnej nawierzchni z białymi wąskim pasami o organicznych kształtach nadających kierunek tej przestrzeni) oraz Red Square (plac którego przestrzen wyróżnia się w krajobrazie miasta jaskrawą posadzk w barwach pomarańczowej, czerwonej i różowej). Cechą zabudowy otaczającej założenie jest różnorodnośc przestrzenna oraz społeczna (międzynarodowy charakter, wielokulturowość). W projekcie Czerwonego Placu zastosowano nawierzchnie z poliuretanu, powłoki tartanowe, asfaltowe oraz ponad 100 rożnych detali urbanino takie 10 różych gatunḱm drzew. Wlacu zasadzo-

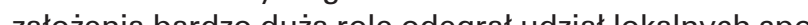
teczności w procesie pla ody

est nieregularna z rozległych barwnych geomemiejch kiektórych Podłużny kierunek podkreślają także: ścieżka rewrow oraz szeregi drzew posadzone wzdłuż niej. Dominantam przestrzennymi placu są trzy duże drzewa z miejscam nasadzeń w formie kolistych podwyższonych płaszczyzn. Silnym elementem przestrzennym jest także ślepa ścia na 5-kondygnacyjnej kamienicy mieszkalnej, na które również zastosowano powierzchnię $\mathrm{w}$ barwie czerwo- nal Square in Dublin (designed by Martha Schwartz, Martha Schwartz Partners, 2007). The square is divided into triangular fields by lines in the floor, filled with hardened surfaces in various colours, grass surfaces and low greenery. The main spatial element of the square is the red surface strip connecting the Grand Canal with Studio Daniel Libeskind's theatre, called the "red carpet" and completed with groups of lamp in the form of tall slender columns in red. The second strip filled with vegetation called the "green carot" che "green carpe building ${ }^{21}$

The cosposition of the square is dynamic, subordinatto the opening direter. This direction is emphasized primarly by a bell and lamps in red, which gives this space a very individual identity. At night, the square has a diterent colour tone - two colours dominate then: red (lamps) and green (highighted edges of triangular fields of green belt.

The role of colour in the directional urban interio One of the most interesting examples of the use of colour in the revitalization of public space with features of a directional interior is the project Superkilen in Copenhagen (designed by Topotek BIG Architects, Superflex, completion 2012). The longitudinal empty space in the compact urban development of the city centre was divided into three zones with a different use: Green Park (linear park as the longest zone), Black Market (transition zone of dark surface with white narrow stripes of organic shapes giving the direction to this space) and Red Square (the square whose space stands out in the townscape by a bright floor in the colors of orange red and pink). A feature of the buildings surround ing the designed space is spatial and social diversity (international character, multiculturalism) In thersity (namere project there were used polyureth s, tartan and asphalt coatings as well as ovurac- 100 differt dies. 10 diferent tee con pla planning process played a very importe role

The composition of the Red Square is irregular, the floor consists of extensive colourful geometric planes, emphasizing in some places the directionality of the revitalized space. The longitudinal direction is also emphasized by: a bicycle path and rows of trees planted along it. The spatial dominants of the square are three large trees with places of planting in the form of circular elevated planes. A strong spatial element is also the blind wall of a 5-storey tenement house, on which the surface in red was also used. Above the bicycle path, spotlights were suspended on the lines. Urba elements and details on the square are used for active and passive recreation. Application of strong stimulat- nej. Nad ściezką rowerową zawieszono na linach punktowe oswietlenie. Elementy i detale urbanistyczne na placu słuzą rekreacji czynnej i biernej. Zastosowanie n bardzo dużej powierzchni silnych pobudzających barw bardzo wyodrębnia tę przestrzeń w krajobrazie miasta i jest ważnym elementem identyfikacyjnym w dzielnicy. Podobny przykład wnętrza kierunkowego rewitalizowanego przy zastosowaniu barwnej posadzki stanow Manly Corso w Sydney w Australii (proj. TCL, Dryden Crute Design, 2008, długość 200 m). Jest to strefa piesza wazzna dla lokalnej spoleczności (przyjazna, egalitarna) ${ }^{2}$ Kompozycja przestrzeni ciągu pieszego jest nieregular na. W posadzce zastosowano granitowe płyty w barwach szarej i jasnożoltej. Płyty zgrupowane są $w$ pasm o nieregularnych krawędziach przypominajacych w rzuku gobrzeczym, ulicy (nieregular zabudowa o wys. 3 kondygnail. W środkowej czéśi ciagu znajduja sie szeregi wysokich drzew palmowych oraz okragte siedziska podświetlon od spodu niebieskim świattem.

Interesujacym przykładem zastosowania silnej barwy w posadzce przestrzeni ulicy jest renowacia ulicy Ru Nova do Carvalho w Lizbonie (proj. José Adrião Arquitectos, realizacja 2013, długość $108 \mathrm{~m}$ ). Posadzka ulicy została pomalowana na różowo w 2011 roku przez lokalnych właścicieli sklepów. Prace konkursowe powstate $w$ roku 2012 postulowały wzmocnienie pierwotnego pomysłu i nadanie mu trwałego charakteru. Projekt ma charakter otwarty, wielofunkcyjny, tworzący dynamiczną przestrzeń publiczną. Barwny chodnik obniżono do poziomu jezdni oraz zaznaczono jego granice białym pasmami. Wzdłuż ulicy, przy której znajdują się także ogrodki kawiarniane usytuowano 8 bilbordów (na rekla$\mathrm{my}$, ogłoszenia oraz słuzące jako lampy ${ }^{24}$.

Wnętrze kierunkowe wąskiej ulicy w zwartej strukturze przestrzennej miasta (pierzeje ulicy mają 4 kondygnacje), dzięki zmianie koloru posadzki nabrało niezwykłego wyrazu przestrzennego. Silna barwa podkresla i wydobywa znaczenie tej ulicy w krajobrazie miasta, nadają jej indywidualną tożsamość

III. 18. Potsdamerstrasse - Bulwar Gwiazd, zespót Potsdamer Platz, Ber-
lin, fot. K. Pluta 2011 / Potsdamerstrasse- The Boulevard of the Stars,
Potsdamer Platz complex, Berlin, photo K. Pluta 2011 ing colours on a very large surface very distinguishes and is an important identification element in the district.

A similar example of a directional interior revitalized Australia (designed by TCL, Dryden Crute Design, 2008 length 200m). It is a the local community (friendly, egalitarian) ${ }^{23}$.

The composition of the route' space is irregular. In the floor there were used granite slabs in grey and light yellow. The plates are grouped in irregularly shaped ands resembling the crests of the sea waves. The belts are located in the transverse direction, which spatially connects both sides of the street (irregular buildings with a height of three floors). In the middle part of the route there are situated rows of tall palm trees and round seats highlighted from underneath with blue light.

An interesting example of using a strong colour in the street floor is the renovation of Rua Nova Street to Carvalho in Lisbon (designed by José Adrião Arquitectos, completion 2013, length $108 \mathrm{~m}$ ). The floor of the street was painted pink in 2011 by local shop owners. The competition works created in 2012 postulated o strengthen the original idea and to give it a lasting character. The project is open, multi-functional, creating a dynamic public space. The coloured pavement was lowered to the level of the road and its borders was lowed to the level of the coloured pave boters roet with café gardens there are localized 8 billboards (for advertisements, announcements and serving as lamps ${ }^{24}$. Directional interior of a narrow street in a compact
spatial structure of the city (street' frontages have spatial structure of the city (street' frontages have
four floors), thanks to the change of the colour of four floors), thanks to the change of the colour of the floor received an extraordinary spatial expression. Strong colour emphasizes the importance of
this street in the townscape, giving it an individual this street
identity.

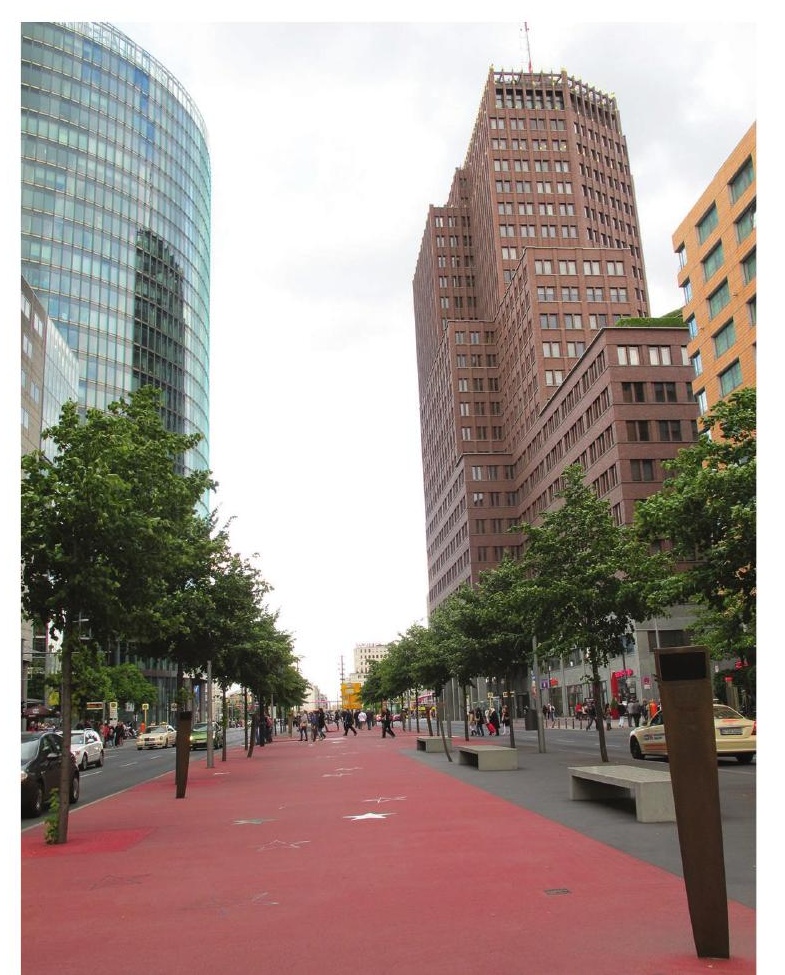


Gtówna ulica w zespole Potsdamer Platz w Berlinie Potsdamerstrasse oddzielająca kwartały Daimler-Benz i Sony została przekształcona w Bulwar Gwiazd, dedykowany Berlinskim celebrytom (proj. Graft, Art.+Com 2009). Srodkowa piesza część ulicy otrzymała posadzk ze sztucznej nawierzchni w kolorze czerwonym, otoczoną z dwóch stron rzędami drzew. W przestrzeń Bulwaru wkomponowano specjalne kamery, siedziska oraz gwiazdy z polerowanego brązu25. Dzięki zastosowaniu silne barwy ciąg pieszy wyróżnia się w krajobrazie zespołu, stanowiąc ważny element tożsamości całego założenia.
(II. 18)

5. Barwna dominanta przestrzenna $i$ barwny akcent 5. Barwna dominanta przestrzena
przestrzenny $w$ krajobrazie miasta

Interesującym przykładem barwnej dominanty przestrzennej przed Szkola Handlowa w Albstadt w Niemw barwie czerwonej. Pawilo szosciennego pawilon znajduje sie w cześci centralnej placu tacząc przestrze nie o różnym sposobie zagospodarowania Naiwieksza przestrzeń podzielona jest na trzy prostokatne trawiaste nawierzchnie, ograniczone cześciowo na krawedziach murkami oporowymi w barwie białej, mogące służyć za siedziska ${ }^{26}$.

Pawilon posiada dach i posadzkę w barwie czerwonej połączone ze soba za pomoca stalowych słupów (brak wypełnienia ścian bocznych). Dzieki silnej barwie i duże skali stanowi barwną dominantę przestrzenną placu. Podobne dominanty przestrzenne, ale o znacznie bardzie skomplikowanych formach, stanowią pawilony $w$ barwie czerwonej znajdujące się w Parc de la Villette w Paryżu (proj. Bernard Tschumi, 1983)27. (II. 19)

Niezwykle interesującym projektem z unikatowym wyrazem kolorystycznym jest Muzeum Ceramiki i Park Mozaiki znajdujące się w Jinzhou w Chinach (proj. Casanova + Hernandez architects, realizacja 2013). Projek jest przykładem wspołczesnego parku miejskiego o hybrydowym charakterze: jest polączeniem krajobrazu naturalnego i miejskiego, architektury i krajobrazu, natury i sztucznego uksztaltowania terenu. Dominanta przestrzenną parku jest Muzeum Ceramiki o nieregularnym kształcie, którego elewacje podzielone są na rozmaite geometryczne pola wypełnione kolorowymi ceramicznymi mozaikami. Mozaiki te utworzone są z połamanych kawałków lokalnej Chińskiej ceramiki. Podobna geome-
trie posiada Park Mozaiki otaczający Muzeum, który skła-

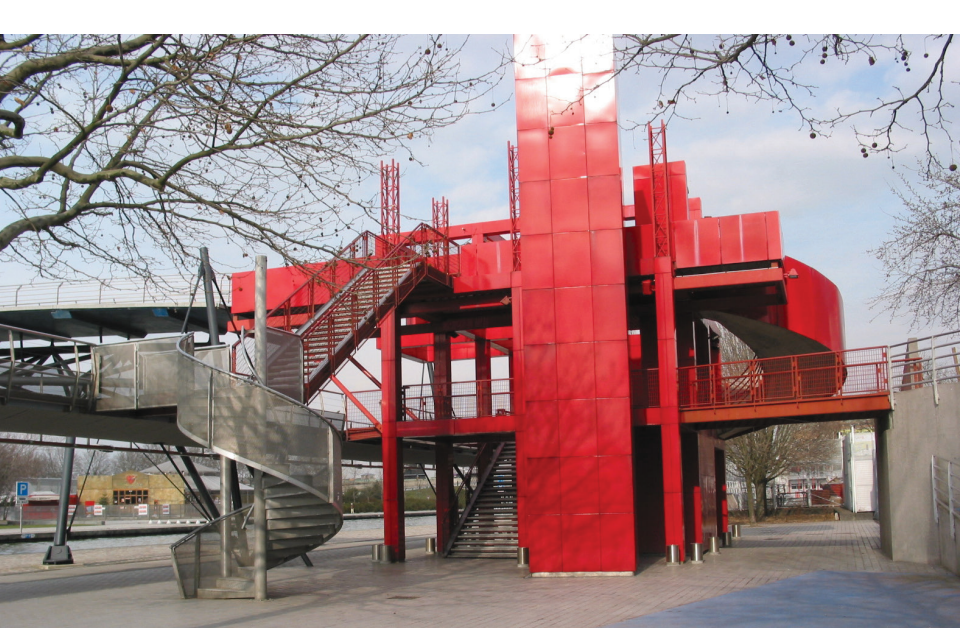

The main street in Potsdamer Platz complex in Berlin (he Daimler-Benz and

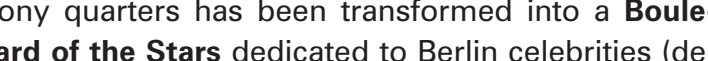
signed by Graft, Art.+Com, 2009). The middle pedestrian part of the street received a floor of artificia surface in red, surrounded on two sides by rows of trees. Special cameras, seats and polished bronze stars have been composed into the space of the Boulevard25. Thanks to the strong colour, the pedestrian route is the special spatial sign in the pede' andscape, constituting an important element of the identity of the whole urban complex.

5. A colourful spatial dominant and a colourful spatial accent in the townscape

An interesting example of a colourful spatial dominant in front of the Trade School in Albstadt in Germany, is the design of a steel cubic pavilion in red. A pavilion with a height of 8 meters is located in the central part of the square, linking spaces of different ways of development. The largest space is divided into three rectangular grass surfaces, partly limite on the edges by retaining walls in white colour, which can be used as seats ${ }^{26}$.

The pavilion has a roof and floor in red colour, connected with each other by steel poles (there are no side walls). Due to its strong colour and large scale, it is a colourful spatial dominant of the square.

Similar spatial dominants, but with much more complex forms, are pavilions in red located in the Parc de la Villette in Paris (designed by Bernard Tschumi 1983 $)^{27}$. (III. 19)

An extremely interesting project with a unique colour expression is Ceramic Museum and Mosaic Park located in Jinzhou, China (designed by Casanova Hernandez architects, completion 2013). The project is a is is an example of a conter tificial iregury

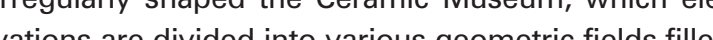
wh colouful ceramic mosaics. These mosaics are

II. 19. Parc de la Villette, Paryż, fot. K. Pluta 2005 / Parc de la Vil-
lette - pavilion, Paris, photo K. Pluta 2005 da się z geometrycznych w planie parterów kwiatowych oraz powierzchni utwardzonych, ktore tworza geometryczne pola. W powierzchniach roslinnych zastosowano cztery gatunki kwiatow o rozznych barwach. Podobne barwy zastosowano na chodnikach wypełnionych kolorowymi ceramicznymi mozaikami oraz na elewacjach Muzeum ${ }^{28}$.

Podobny układ geometryczny wszystkich elementów zespołu jak i zbliżona kolorystyka powoduje, że układ przestrzenny parku i budynku ma jednolity charakter jednoczesnie silną indywidualną tozsamość. Jest to bardzo oryginalne iunikatowe rozwiąznie, prezentując całościową koncepcję kolorystyczną

Dominantami barwnymi w dużej skali są drzewa w Gardens by the Bay (Ogrodach przy Zatoce) $w$ Singapurze bej (proj. Grant Associates ryalizaci 2012) oraz a jick South Park a Aren Elizabeth Olympic Park w Londyou (proj. Anish Kap Liz 2015) ze stalowych elementów w barwie czerwonej29.

Przykładem barwnych akcentów przestrzennych w prze strzeni publicznej sa duże kwiaty w barwie czerwone (ze stali i włókna szklanego), znajdujące się w zewnetrznej przestrzeni zielonej przy Muzeum MAXXI projekt Zahy Hadid w Rzymie (Whatami", proj. stARTT, realizacja 2011)

Inny rodzaj akcentów przestrzennych barwnych tworza partery kwiatowe $w$ barwie czerwonej o organicznych kształtach, zaprojektowane w parku Jubilee Garden nad Tamizą w Londynie (proj. West 8 urban design landscape architecture, realizacja 2012) ${ }^{31}$.

\section{Wpływ sztuki na kształtowanie przestrzeni}

publicznych

Piazza Matteotti znajduje się w mieście Catanzaro w południowych Włoszech. W latach 80-tych XX wieku plac, ktorego forma przestrzenna ksztattowana byla ponad sto lat, wypełniony był samochodami zarówno na jezdniach, jak i zaparkowanymi w części środkowe placu. W latach 1989-1992 plac poddano rewitalizac (proj. Franco Zagari, Enzo Amantea, Antonio Uccello, erdinando Gabellini, Giovanni Laganả), która polegata przede wszystkim na przekształceniu układu drogowego i wprowadzeniu większych powierzchni dla pieszych. Częsć pieszą uksztattowano $w$ formie promenady, placu lementem przestrzennym jest promenad, któn tworzy rzad palm, ciag kamiennych tamek o organicznej lini przebiegu oraz posadzka $z$ czarnego granitu $i$ jasnego trawertynu swo bodni inspirowana dzietem masnego tora Vasarely'ego. Na obu końcach promenady usytuowano otwarte niewielkie w skali pawilony. W środkowe cześci założenia na placu usytuowano zegar słoneczny oraz rzeźbe- schody, z których można było obserwowa plac z wyższego poziomu. W roku 2015 powstał drug projekt, stanowiący kolejna rewitalizacje placu. Schody zastąpione zostały szklaną fontanną położona $w$ tym sa mym miejscu co schody (w planie w kształcie trójkata) ${ }^{32}$ Piazza Matteotti - to niezwykły przykład rewitalizacji przestrzeni publicznej, w którym ważną rolę odgry- created with broken pieces of local Chinese ceramics. A similar geometry is introduced in the Mosaic Park surrounding the Museum, which consists of geometric planes of flower beds and hard surfaces that create geometrical fields. Four species of flowers of different colors were used in plant surfaces. Similar colors were used on pavements filled with colourful ceramic mosaics and on the facades of the museum ${ }^{28}$.

Similar geometric arrangement of all elements of the complex as well as similar colours effects that the spatial ayout of the park and the building has a unified character and at the same time a strong individual identity. It is a very original and unique solution presenting a total colour concept.

The colour spatial dominants on a large scale are trees in Gardens by the Bay in Singapore, made of steel elements in purple (designed by Grant Associates, completion 2012), and the ArcelorMittal Orbit observation tower in the South Park at Queen Elizabeth Olympic Park in London (designed by Anis Kapoor 2015), made of steel elements in red ${ }^{29}$.

An example of colourful spatial accents in public space are large flowers in red (made of steel and fiberglass), located in the outer green space near the MAXXI Museum designed by Zaha Hadid in Rome ("Whatami", designed by stARTT, completion 2011) (30. $^{3}$ Another type of colour spatial accents are created by red flowerbeds in organic shapes, designed in the Jubilee Gardens near the River Thames in London (designed by West 8 urban design \& landscape architecture, completion 2012) ${ }^{31}$.

6. The influence of art on shaping public spaces Piazza Matteotti is located in the city of Catanzaro in southern Italy. In the 80s of the twentieth century, the square, whose spatial form was shaped over one hundred years, was filled with cars both on the roadways and parked in the central part of the square. In the years 1989-1992 the square was revitalized (designed by Franco Zagari, Enzo Amantea, Antonio Uccello, Ferdinando Gabellini, Giovanni Laganà), mainly by the ransformation of the road system and the introduction of larger areas for pedestrians. Pedestrian area was formed as a promenade, square and park in front of the palace. The most characteristic spatial element is the promenade, which is shaped by a row of palm trees, a series of stone benches with an organic form and a floor constructed by black granite and light travertine freely inspired by the work of painter Victor Vasarely. At both ends of the promenade, small scale open pavilions were located. In the middle part of the square, there was located a solar clock and a sculpture - stairs from which one could observe a square from a higher level. In 2015, a second project was created, constituting another revitalization of the square. The stairs have been replaced with a glass fountain located in the sam place as the stairs (in plan in shape of a triangle) ${ }^{32}$. 


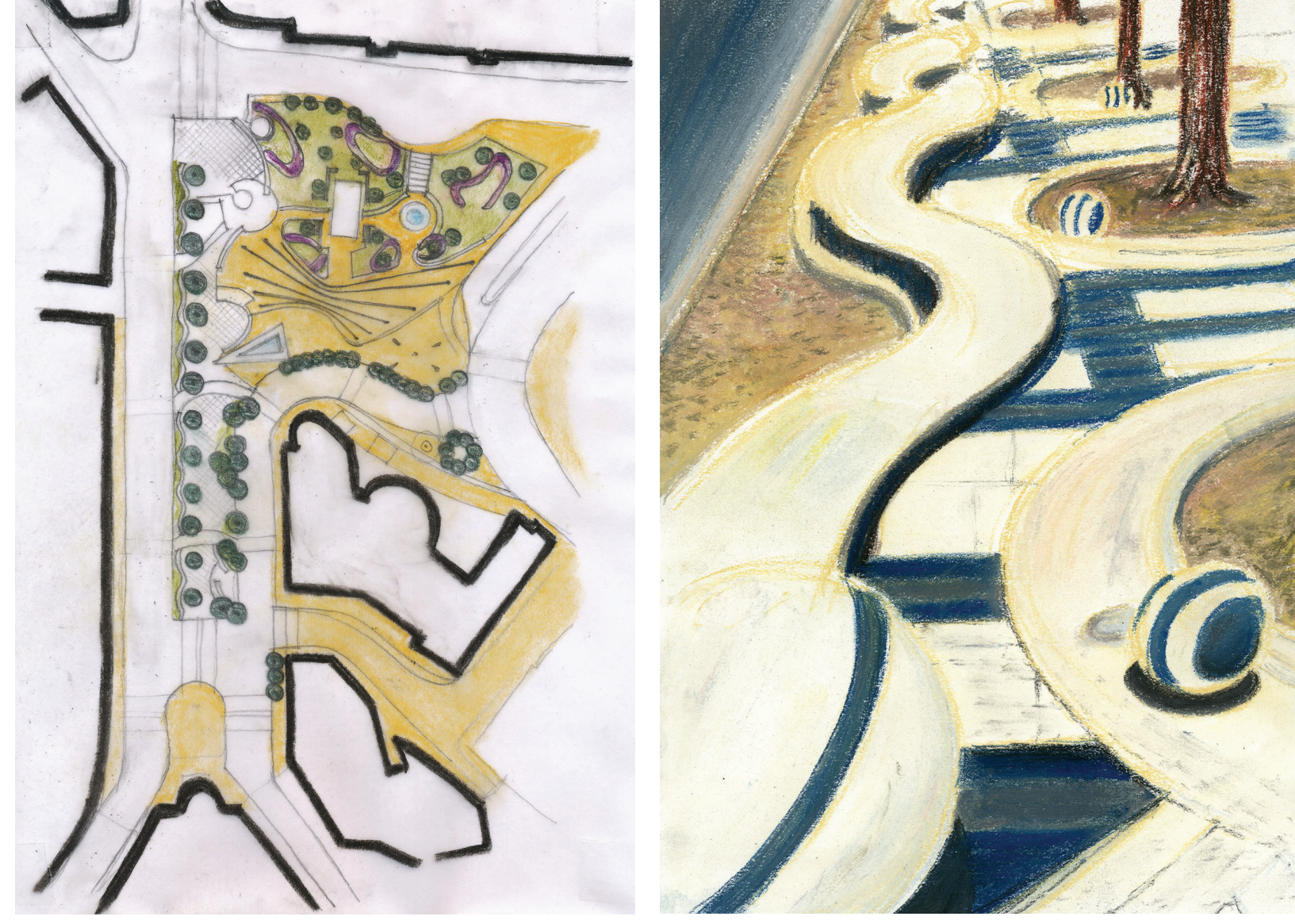

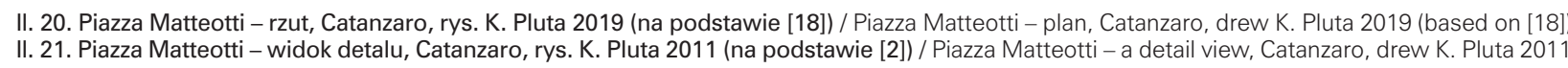

wa barwa, stosowana na nowej posadzce założenia i rozmaitych elementach przestrennych. W posadzce promenady inspirowanej malarstwem znanego arty sty, dominują dwie kontrastujące barwy: czarna i szara (paski) oraz jasna o kremowym odcieniu (kwadratowe pola). W podobnej jasnej barwie wykonane sa kamienne ławki oraz kule. Dzięki takiemu rozwiązaniu promenada jest najbardziej charakterystycznym elementem całego założenia i stanowi o jego tożsamości.
(II. 20, 21) (II. 20, 21)

Podobny przykład to projekt parku Joan Miró w Paryżu - innowacyjne rozwiązanie polegające na wzajemnym oddziaływaniu rosilinnosci, barwnych nawierzchni inspitowany halosswem Joan Mró oraz zrożnicowane monotonna zabudowa mieszkaniowa stata sie trem dla oryginalnego krajobrazu parku.

7. Zastosowanie barwnych elementów liniowych w krajobrazie miasta Jednym $z$ interesujących rozwiązań elementów liniowych w krajobrazie miasta jest projekt Promenady w Be(proj. OAB- Carlos Ferrater \& Xavier Marti, 2009). Jest to przestrzeń publiczna w dużej skali zapewniająca różnorodne aktywności. Promenada zaprojektowana jes w postaci platformy o organicznych ksztattach (przypominających formy fal) i o różnych nawierzchniach we wszystkich kolorach ${ }^{3}$.

Posadzka promenady ma różne faktury, a jej barwy zmieniają się od odcieni niebieskiego, przez fiolety, barwę czerwoną pomarańczową, żóttą do zielonej (użyto pra-
Piazza Matteotti - is an unusual example of the revitalization of public space, in which the important role play colour, used on the new floor and in various spatial elements. The floor of the promenade, inspired by the painting of a well-known artist, is dominated by two contrasting colors: black and grey (stripes) and light with a cream shade (squares). The similar light colour have stone benches and stone balls. Thanks to such a solution, the promenade is the mos characteristic element of the whole public space and determines its identity. (III. 20, III. 21)

A similar example is the design of the Joan Miro Park action of vegetation, colourful surfaces inspired by Joan Miro painting and diversified topography. The high monotonous housing development dominating the park space has become the background for the park's original landscape.

7. Application of coloured linear elements in the townscape

One of the interesting solutions of coloured linear elements in the townscape is the Promenade in $\mathrm{Be}$ nidorm in Spain, adjacent to the western beach (designed by OAB- Carlos Ferrater \& Xavier Marti, 2009). It is a public space on a large scale providing various activities. The promenade is designed in the form of forms) and different surfaces in all colours $\mathrm{s}^{33}$.

The floor of the promenade has different textures, and its colours vary from shades of blue, purples, red, orin Paris - an innovative solution based on the intera platform with organic shapes (resembling wave wie całej gamy kolorystycznej). Barwna platforma uzupelniona jest krzewami w częsciach poszerzonych oraz linearnymi siedziskami, z ktôrych rozpościera się wido na morze. Od strony miasta do promenady przylega ulica oraz zabudowa mieszkaniowo-usługowa ( $w$ tym zabudowa wysoka). Dzięki unikatowym ksztaltom i kolorystyce, promenada stala się ważnym elementem przekowym w krajobrazie, łączącym plaż z miastem

8. Barwne rozwiązania elementów przestrzennych ymczasowych

W lutym 2005 roku przez 16 dni eksponowana była $w$ Central Park w Nowym Yorku instalacja tymczasowa nazwana "The Gates", która składała się z 7503 bram (bramy $4,87 \mathrm{~m}$ wysokości i $1,68 \mathrm{~m}-5,48 \mathrm{~m}$ szerokóci odlegtość miedzy bramami 3,65 m). Odwiedzaiacy park przechodzili pod ruchomym falujacym zadaszeniem (proj. Christo i Jeanne-Claude Nowy Jork, USA, 2005)34. Kompozycia zatozienia opiera sie na odcinkach prostych i zakrzywionych na których ustawiono bramy, co pozwolito na uzyskanie wrażenia spaceru w parku w róż nych kierunkach pod dachem w ostrej barwie pomarań czowo-żóttej, stanowiącym duży kontrast kolorystyczny $z$ otoczeniem w porze zimowej (powierzchnie trawiaste przykryte białym śniegiem i szaro-brazowe pnie i korony drzew).

Innym przykładem tymczasowych elementów przestrzennych są kinetyczne linearne struktury składające się z cienkich pionowych elementów w silnych czerwonych, żołtych i pomaranczowych barwach przewagą koloru czerwonego). Są to rzeźby zaprojektowane przez Konstantina Dimopoulosa, sytuowan W krajobrazie miejskim - W przestrzeniach publicznych placow, parkow i ulic. Elementy poruszane są przez wiatr i deszcz, tworząc ruchome rzeźby w przestrzen przypominające zmienne elementy natury (proj. Konstantin Dimopoulos, od 2007 roku sytuowane w wielu lokalizacjach). Rzeźby stanowią wyraźne akcenty $w$ przestrzeni, oddziałujące na obserwatora za pomo cą formy i barwy ${ }^{33}$

9. Podsumowanie

Kształtowanie oryginalnych i o wysokiej jakości założen urbanistycznych i krajobrazowych w miastach, w kompozcji danego miejsa lub colego mista oraz powinno przyczynić sie do powstrzymania procesu degradacij i ujednolicania krajobrazu wspótczesnych miast. Zwłaszcza wprowadzanie rozwiazań inspirowanych historia rozwo ju okolicy, lokalnym kolorytem i zagospodarowaniem obszaru, powoduje zarówno podtrzymanie lokalnego charakteru danego miejsca, jak i kształtowanie nowe tożsamości założenia. Dzięki symbiozie różnorodnych form przestrzennych, zastosowanych materiałów i detali urbanistycznych o określonej kolorystyce oraz różnych rodzajów zieleni i oswietlenia sztucznego powstaj nowe krajobrazy miejskie. ange, yellow to green (almost the whole range of colwith shrubs in extended parts and linear seats, from which there is a view to the sea. From the city side, the street is adjacent to the promenade as well as housing and service buildings (including high buildings). Thanks to the unique shapes and colours, the promenade has become an important spatial directional ele-

8. Coloured solutions of temporary spatial elements In February 2005, for 16 days, a temporary installation called "The Gates" was exposed in Central Park in New York, which consisted of 7503 gates decorated with pane of saffron-coloured fabric (gat $4.87 \mathrm{~m}$ high and $1.08 \mathrm{~m}-5.48 \mathrm{~m}$ wide, distace $4.87 \mathrm{~m}$ high and $1.68 \mathrm{~m}$. Visitors of the park panced under a moving wavy roof (designed by Christo and Jeanne-Claude, New York, USA, 2005 ${ }^{34}$.

The composition of the structure was based on straight and curved sections on which the gates were locight and curved sections on which the gates were ing in the park in various directions under the roo in a strong orange-yellow colour, which was in a big colour contrast with the surroundings in the winter time (grassy areas covered with white snow and grey-brown trunks and tree crowns).

Another example of temporary spatial elements are kinetic linear structures consisting of thin vertica elements in strong red, yellow and orange colours (with a predominance of red). These are sculptures designed by Konstantin Dimopoulos, placed in the urban landscape - in the public spaces of squares, parks and streets. Elements are moved by wind and rain, creating moving sculptures in space, resembling changing elements of nature /designed by Konstantin Dimopoulos, situated in many locations since 2007). The sculptures are distinct accents in space,

\section{Summary}

Shaping the original and of high-quality urban and andscape solutions in cities, in which compositions special attention is payed to the use of colour, affects shaping of the identity of a place or the entire city and should help to stop the degradation and unification of the townscape of contemporary cities. In particula the introduction of solutions inspired by the history of the development of the area, local colour and presen development of the area, both sustains the local character of the place, as well as shaping the new identity of the solution. Thanks to the symbiosis of various spatial forms, applied materials and urban details of a specific colour and various types of greenery and artificial lighting, new urban landscapes are created.

Autor ttumaczenia: Katarzyna Pluta 
PRZYPISY

K. Wejchert, Elementy Kompozycii Urbanistycznej, Arkady, WarszaWa 1984, s. 201
I Jbidem, s. 221

3/bidem, s. 206.
4/bidem, s. 206.

Ibidem, s. 206.

Ibidem, s. 2217.

8 l bidem, s. 207, 217.
9 lbidem, s. 218, 221, 222

${ }_{10} \mathrm{~K}$. Pluta, Przestrzenie publiczne miast europejskich. Projektowanie 2. poprawione, 2014, Warszawa. 1" M. Ruano, Ecoulrbanism, sustainable human settlements: 60 case studies, Editorial Gustavo Gill, SA, Barcelona 1999, s. 100, 102.250.
${ }_{12}$ M. Treib. Disturbed terrain, w: Becker A., Cachola Schmal P. . Eds.) Urban Green. European Landscape Design for the 215t century, Birk-
hauser GmbH, Deutsches Architekturnuseum, Basel, 2010, s. 16-24:
J. Krauel, Urban Spaces: New City Parks, LINKS, Barcelona 2008. s. 190. 147 . Heinrich, Duisburg-Nord Landscape Park, w: Under the Open Sky. C. Heinrich, Duisburg-Nord Landscape Park, w: Under the Open Sky.
Emscher Landscape Park, Birkhäuser GmbH, Basel, 2010, s. 64-71.
13 . 13
13 Kombol M., Landscape Architecture, Phaidon Press Limited, 2015,
s. 144,145

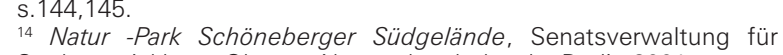

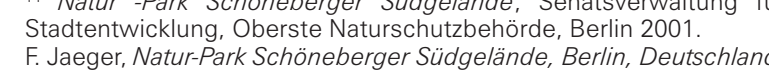
F. Jaeger, Natur-Park Schöneberger Südgelände, Berlin, Deutschland, W: A.Becker, P. Cachola Schmal (Eds.), Urban Green. European Lan Ar-
scape Design for the $21 s t$ century. Birkhauser GmbH, Deutsches Architekturmuseum, Basel, 2010, s. 54-59.
K. Pluta, Przestrzenie publiczne miast europejskich..., op. cit., 2014. ${ }_{15} \mathrm{H}$. Rauterberg, Hit the squares! What do communal spaces need? An exploration, W: Hamburg: Parks and Squares for the Developing
City, Free and Hanseatic City of Hamburg, State Ministry for Urban Development and Environment (BSU), jovis Verlag GmbH, 2008, s.
$17-25,60-61$. Ch. Hölzer, T. Hundt, C. Lüke, O.G. Hamm, Riverscapess. Designing ${ }_{16}^{16} \mathrm{Ch}$. Hölzer, T. Hundt, C. Lüke, O.G. Hamm, Riverscapes...., op. cit.

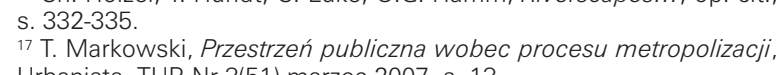
17. Markowski, Przestrzen publictrna wobec
Urbanista, TUP, Nr (51) marzec 2007, s. 13. ${ }_{11}^{18} 7000 \times$ Landscape Architecture, Verlagshaus Braun, 2009, s. 469. $191 \mathrm{lbidem}, \mathrm{s.48}$
$20 \mathrm{lbidem}, \mathrm{s} .580$

${ }_{21}^{21}$ Kombol M., Landscape Architecture, op. cit., s.272, 273.
2. .S. Braun, C. Uffelenv, Atlas of Word Landscape Architecture, 22 M.S. Braun, C. Uffelenv, At/ss or
Braun Publishing AG, 2014, s.38; Braun Publishing AG, 2014, s.38;
C. Uffelenv, Pedestrian Zones. Car-Free Urban Spaces, Braun Publish${ }_{23}$ C. Uffelenv, Pedestrian Zones, op. cit., s.70-73

${ }^{24}$ Cbidem, s.20,21.
${ }^{25}$ M.S. Braun, C. Uffelenv, Atlas of Word..., op. cit., s. 78,79 .

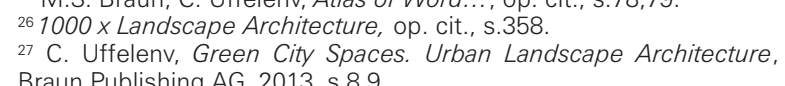
Braun Publishing AG, 2013, s.8.9.

${ }_{22}^{2}$ M.S. Braun, C. Uffelenv, Atlas of Word..., op. cit, s.350-351.
Cffelenv, Green City Spaces..., op., citt, s.12-15, Kombol M.

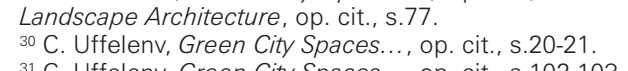
32 J.Gehl, L.Gemzoe, New city spaces, The Danish Architectural Press, Cope 32 Gt 201, tanzaro-2007-2015) (dostęp 23.07.2019). http:) / / www.francozagari. it) project) catanzaro-matteotti-1991) (dostepp 23.07. 2019).
33 M.S. Braun, C. Uffelenv, Atlas of Word..., op. cit., s.218,219. ${ }_{33}^{33}$ M.S. Braun, C. Uffelenv, Attas of Word..., op. cit., s.218,219. ${ }^{35}$ M.S. Braun, C. Uffelenv, Atlas of Word..., op. cit., s.296-297.

\section{LITERATURA}

[1] Braun M.S., Uffelenv C., Atlas of Word Landscape Architecture, [2] Gehl I., Gemzes L.., New city spaces, The Danish Architectural [3] Heinrich C Duishurg-Nord Landscape Park w. Under the Open Sky. Emscher Landscape Park, Birkhauser GmbH, Basel, 2010. [4] Hölzer Ch., Hundt T., C. Lüke, O.G. Hamm, Riverscapes. Designing
Urban Embankments, Birkhäuser Verlag AG, 2008 . [5] Jaeger F., Natur-Park Schoneberger Sudgelande, Berlin, Deutschland, w: A.Becker, P. Cachola Schmal (Eds.), Urban Green. European Architekturmuseum, Basel, 2010.

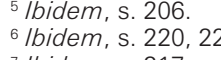

7 lbidem, s. 217.2
8 lbidem.s 207.217

9 lbidem, s. 218, 221, 222

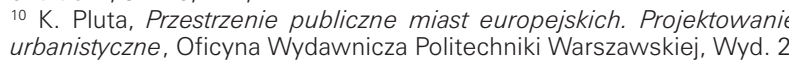
poprawione, 2014, Warszawa.
${ }_{11} \mathrm{M}$. Ruano, EcoUrbanism, sustainable human settlements: 60 case

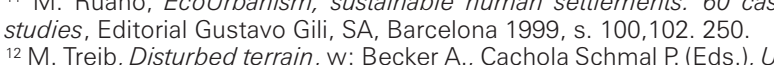
ban Green. European Landscape Design for the 21st century. Birkhauser J Krat, Uroan Spaces: Now City Park, LNKS, Baro C. Heinrich, Duisburg-Nord Landscape Park, w: Under the Open Sky. Em-

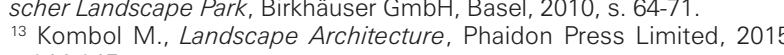
S.144,145. entwicklung Oberste Naturschutzbehörde, Berlin 2001 F. Jaeger, Natur-Park Schöneberger Südgelände, Berlin, Deutsch Landscape Design for the 21 st centurn. Birkhäuser GmbH, Deutsches Architekturmuseum, Basel, 2010, s. 54-59.

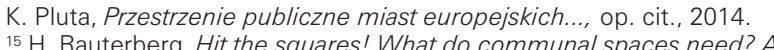
exploration, w: Hamburg: Parks and Squares for the Developing City. lopment and Environment (BSU), jovis Verlag GmbH, 2008, $s$. 17.25. Co-61. Hölzer, T. Hundt, C. Lüke, O.G. Hamm, Riverscapes. Designing Ur ${ }_{16} \mathrm{Ch}$. Hölzer, T. Hundt, C. Lüke, O.G. Hamm, Riverscapes..., op. cit.. s. Urbanista. TUP. Nr 3151 marzec 2007. s. 13 . 187000 x Landscape Architecture, Verlagshaus Braun, 2009, s. 469 $19 \mathrm{lbidem}, \mathrm{s.48}$
$20 \mathrm{lbidem}$ s. 580

${ }^{21}$ Kombol M., Landscape Architecture, Phaidon Press Limited, 2015,

5.272.273
22 M.S Braun, C. Uffelenv, Atlas of Word Landscape Architecture, Braun
Publishing AG 2014, S2 Publishing AG, 2014, s.38; C. Uffelenv, Pedestrian Zones. Car-Free Urban Spaces, Braun Publishing ${ }_{23} \mathrm{C}$. Uffelenv, Pedestrian Zones. Car-Free Urban Spaces, op. cit., s.7073.
24 bidem, s. $20,21$.

${ }_{25}^{25}$ M.S.S. Braun, C. Uffelenv, Atlas of Word..., op. cit., s.78,79.

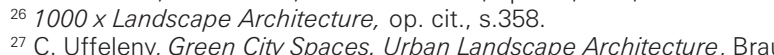
Publishing AG, 2013, s.8,9.

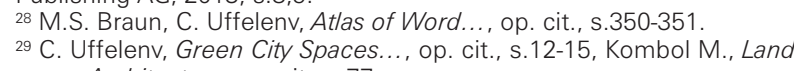

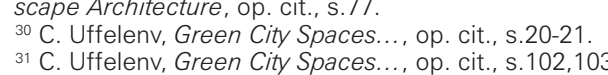

32. Gele tr, Green City Spaces..., op. cit., s. $102,103$. 32.Gehl, L.Gemzoe, New city spaces, The Dar
Copenhagen 2001, s.202-207:
1000 x Landscape Architecture, op. cit., s.632:

( ro-2007-2015) (dostep 23.07 2019) hittp:) Www.francozagari.it) project) catanzaro-matteotti-1991) (dostęp ${ }_{33}$ M.S. Braun, C. Uffelenv, Atlas of Word..., op. cit., s. 218,219 . $34,000 \times$ Landscape Architecture, op. cit.,. 5.293.
35 M.S. Braun, C. Uffelenv, Atlas of Word.... op. cit., s.296-297.

\section{BIBLIOGRAPHY}

[1] Braun M.S., Uffelenv C., Atlas of Word Landscape Architecture. Braun Publishing AG, 2014.
[2] Gehl J., Gemzroe L., New city spaces, The Danish Architectural Press. [3] Heinrich C., Duisburg-Nord Landscape Park, w: Under the Open Sky

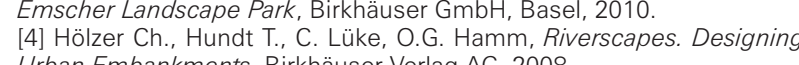
Urban Embankments, Birkhäuuser Verlag AG, 2008 .
[6] Kombol M., Landscape Architecture, Phaidon Press Limited, 71) Kravel J, Urban Spaces: New City Parks, LNKS, Barcelona 2008.
$[88000 \times$ Landscape Architecture. Verlagshaus Braun, 2009. Zacji, Urbanista, TUP, Mr 3151) marzec 2007. Ne) Natur - Park Schoneberger Sudgelande, Senatsverwaltun 11] Pluta K., Przestrzenie publiczne miast europeiskich. Projektowanie unbanistyczne, Oficyna Wydawnicza Polltech iki Warszawskiej, Wyd. 2. poprawione, 2014, Warszawa
[12] Rauterberg H., Hit the squares! What need? An exploration, w: Hamburg: Parks and Squares for the stry for Urban Development and Environment (BSU), Stavis Min GmbH, 2008. Ecourbanism, sustainable human settlements: 60

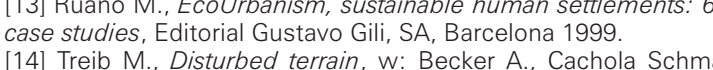
[14] Treib M., Disturbed terrain, W. Becker A.' Cachola Schm century. Birkhauser GmbH, Deutsches Aron
sel, 2010 . 15] Uffelenv C., Green City Spaces. Urban Landscape Architecture, Braun Publishing AG, 2013. . CrFre Urban Spaces, Brau
[16. Uffelenv C. Pedestrian Zones. Car-Free Ur. Publishing AG, 2015 .
$[17]$ Wejchert K., Elementy Kompozycji Urbanistycznej, Arkady. Warszawa 1984.

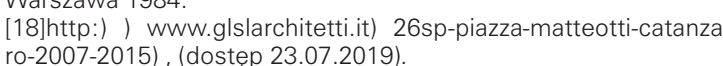

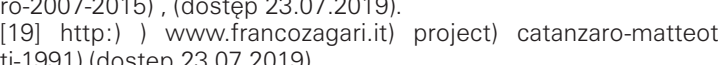

(5) Jaeger F, Natur-Park Schöneberger Südgelände, Berlin, Deutschland,

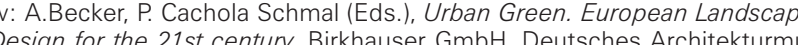
seum, Basel, 2010

. Landscape Architecture, Phaidon Press Limited, 2015. [8] 1000 x Landscape Architecture. Verlagshaus Braun, 2009. [9istarkowski T. 110] Natur - Park Schöneberger Südgelände, Senatsverwaltung für Stad11] Pluta K., Przestrzenie publiczze miast europejskich. Projektowanie ur.

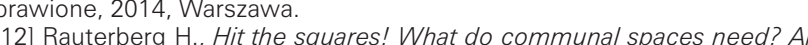
exploration, w: Hamburg: Parks and Squares for the Developing City, Free and Hanseatic City of Hamburg, State Ministry for Urban Development and [13] Ruano M. Ecoulrbanism sustainable hum 144] Treib M., Disturbed terrain, W: Becker A., Cachola Schmal P. (Eds.), Ur GmbH. Deutsches Architekturmuseum, Basel, 2010.
$[15]$ Uffelenv C.. Green City Spaces. Urban Landscape Architecture, Brau Publishing AG, 2013.
[16] Uffelenv C., Ped

es. Car-Free Urban Spaces, Braun Publis 17] Wejchert K., Elementy Kompozycii Urbanistycznej, Arkady, Warszaw 1984http:) www.glslarchitetti.it) 26sp-piazzza-matteotti-catanzaro-2007-2015

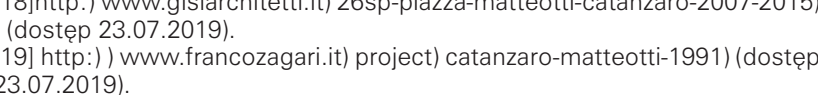

